\title{
PERSEPSI VISUAL KARAKTER WARRIOR PADA GAME ONLINE WARCRAFT, PERFECT WORLD, DAN NUSANTARA ONLINE
}

\author{
Abi Senoprabowo ${ }^{1}$, Khamadi ${ }^{2}$, Toto Haryadi ${ }^{3}$, Hen Dian Yudani ${ }^{4}$ \\ 1,2,3 Universitas Dian Nuswantoro, ${ }^{4}$ Universitas Petra
}

\begin{abstract}
Abstrak : Visual merupakan aspek utama dalam perancangan game, sebagai stimulus yang mendorong subyek memberikan interpretasi dari berbagai aspek. Salah satu unsur visual yang penting yaitu karakter. Karakter membuat pemain menjadi fanatik, sehingga mendorongnya untuk memainkan karakter yang dianggap mewakili jati dirinya. Banyak game menjadi populer dikarenakan keunikan dari karakternya. Karakter tipe warrior menjadi karakter yang sering dipilih oleh pemain khususnya untuk genre Massively Multiplayer Online Role Playing Game (MMORPG) karena keunggulannya dalam skill kekuatan, pertahanan, ketangkasan, dan kecepatan dalam pertarungan jarak dekat. Dalam penelitian ini, karakter dipilih berdasarkan game MMORPG bertema Eropa, Asia, serta Indonesia. Perbedaan budaya pada setting tempat MMORPG membuat tampilan visual dari karakter warrior juga berbeda satu sama lain. Berdasarkan hal tersebut, penelitian ini dilakukan untuk mengetahui kecenderungan persepsi visual dari audiens dalam memilih karakter game online. Penelitian ini menggunakan paradigm pendekatan kuantitatif dengan metode pengumpulan data menggunakan VAS (Visual Analog Scale) dan metode analisis ANOVA (Analysis of Variance). Hasil dari penelitian ini adalah parameter seperti: perupaan karakter, armor, serta aksesoris dan senjata menjadi pertimbangan utama audiens dalam memilih karakter warrrior yang ideal. Sedangkan gender tidak menjadi faktor utama dalam pemilihan karakter.
\end{abstract}

Kata kunci : Persepsi Visual, Karakter, Warrior, Game Online, MMORPG

\begin{abstract}
Visual is main aspect in the game development, as a stimulus which encourages subjects to give interpretation of various aspects. One of important visual elements is character. Character motivates players become fanatic, thus encourages them to play the character which is considered to represent their identity. Many games become popular because of the uniqeuness of character. Warrior characters often chosen by the player, specifically for the Massively Multiplayer Online Role Playing Game (MMORPG) genre, due to their superiority in strength, defense, agility
\end{abstract}

\footnotetext{
1,2,3Penulis adalah pengajar pada Program Studi DKV Fakultas IImu Komputar, Universitas Dian Nuswantoro, email: ${ }^{1}$ abiseno.p@gmail.com, ${ }^{2}$ khamadi@dsn.dinus.ac.id, ${ }^{3}$ toto.haryadi@dsn.dinus.ac.id ${ }^{4}$ Penulis adalah pengajar Universitas Petra, email: hendiyan97@yahoo.com
} 
and speed skills in close combat. In this research, characters which are selected based on MMORPG games which themed Europe, Asia, and Indonesia. The difference of culture on MMORPG game's setting make the visual appearance of the warrior character also different from each other. Based on that case, this research was conducted to determine the tendency of visual from audiences in choosing the character of online game. This research uses quantitative approach with data collection method using VAS (Visual Analog Scale) and ANOVA (Analysis Variance). The results is some parameters such as: character visualization, armor, accessories and weapons are become primary consideracy for player in choosing the ideal warrior character. While the gender is not a major factor in that case.

Keywords: Visual Perception, Character, Knight, Online Game, MMORPG

\section{PENDAHULUAN}

Visual merupakan salah satu aspek terpenting dalam membangun aset yang berkaitan dengan seni dan desain (Pattiasina, 2014). Nilai estetis dari desain khususnya desain komunikasi visual dan desain grafis, terletak pada tampilan visualnya. Visual memegang peranan penting berkaitan dengan suatu produk desain. Prioritas seseorang dalam menilai baik buruknya, serta estetis tidaknya sebuah produk desain, direpresentasikan melalui visual. Visual sebagai salah satu stimuli yang ditangkap indera mata, akan menyebabkan subyek yang mengamatinya memberikan suatu interpretasi atau penafsiran (Salma, 2012). Hasil dari penafsiran tiap individu adalah berbeda-beda. Hal ini dikarenakan visual dari suatu hasil desain dapat dinilai dari berbagai aspek, yang dikaitkan dalam beberapa ilmu studi lain yang ada dalam kehidupan.

Game sebagai salah satu produk desain, merupakan hiburan yang banyak digemari oleh masyarakat berbagai kalangan. Game yang beredar di masyarakat baik yang tertanam pada perangkat mobile, console, maupun $P C$, telah menjadi aktivitas di waktu senggang dan untuk menghilangkan kepenatan akibat rutinitas dalam kehidupan sehari-hari. Nilai jual dari game terletak pada cerita serta tampilan visual yang dimilikinya. Unsur-unsur yang membangun game seperti: 
karakter, lingkungan, user interface (antarmuka tampilan), animasi, fade in/fade out didesain sedemikian rupa sehingga membuat orang yang memainkan tidak jenuh dan bisa berinteraksi untuk meyelesaikan misi dalam game (Senoprabowo, 2015).

Berdasarkan beberapa unsur-unsur pembangun game seperti yang telah disebut di atas, karakter merupakan elemen visual yang paling penting (Khamadi, 2015). Karakter merupakan representasi dari pemain yang memainkan game. Karakter membuat pemain menjadi fanatik. Pemain cenderung memainkan karakter yang menjadi pilihannya sejak awal, yang dianggap mewakili identitas atau jati dirinya (Khamadi and Senoprabowo, 2016). Karakter sebagai elemen dramatis dalam game, secara tidak langsung menjadi 'nyawa' dari produk game itu sendiri. Banyak game yang laku keras dikarenakan keunikan dari karakternya, seperti Game Mario Bros (Bastian \& Khamadi, 2016).

Semakin banyaknya produk game berkarakter unik yang ditawarkan, membuat pemain berusaha untuk mencoba berbagai game itu. Khususnya game online, yang merupakan game dengan pilihan karakter terbanyak. Hampir semua game online memiliki karakter yang dibedakan mulai dari jenis kelamin, tugas yang diemban, jenis spesies, serta kedudukan atau strata karakter itu dalam dunia game (Estidianti \& Lakoro, 2014). Seperti dalam game online bergenre Massively Multiplayer Online Role Playing Game (MMORPG) setiap karakter memiliki identitas, tugas, serta kedudukan masing-masing seperti: raja, petarung jarak dekat (warrior), petarung jarak jauh, penyihir, prajurit, dan lain sebagainya (Pusposari and Lakoro, 2017). Setiap karakter memiliki keunikan yang tidak dimiliki karakter lain.

Karakter tipe warrior merupakan petarung jarak dekat yang dapat bertarung dengan atau tanpa menggunakan senjata. Mereka sangat tangkas dan 
cepat dalam menyerang dan menghindar. Mereka merupakan ahli dari segala jenis ilmu pertarungan. Mereka mempunyai keseimbangan dalam menyerang dan bertahan, mereka juga dapat menggunakan tipe senjata yang berbeda, hebat dalam pukulan fisik dan teknik bertarung. Sehingga dapat membuat kombinasi mematikan dari kekuatan dan kecepatannya. Kemampuan ini menjadikan karakter tipe warrior sering dipilih oleh pemain dibanding karakter tipe lain yang cukup berbeda jauh di kemampuan menyerang dan bertahannya. Karakteristik warrior dalam MMORPG dipengaruhi oleh dimana tempat lahirnya game tersebut. Terdapat MMORPG tipe Eropa, Asia, serta Indonesia. Perbedaan budaya tempat MMORPG dibuat, membuat tampilan visual dari karakter warrior juga berbeda satu sama lain. Visual yang ada pada karakter seperti karakteristik wajah, karakteristik badan, baju pelindung tubuh, asesoris, serta senjata yang digunakan, cenderung merepresentasikan budaya yang ada. MMORPG yang berasal dari Eropa, menampilkan karakteristik suku serta budaya khas Eropa. MMORPG dari Asia, merepresentasikan budaya Asia, khususnya Korea. MMORPG dari Indonesia, juga mengangkat budaya Indonesia. Ketiga zona tersebut di atas, secara tidak langsung menggiring pemain untuk memilih salah satu karakter dari yang ada.

Keberagaman karakter warrior dalam game online khususnya MMORPG, membuat tiap pemain memilih karakter yang disukainya sesuai keinginan hatinya, yang berasal dari ketiga zona tersebut di atas. Berangkat dari masalah di atas, dilakukanlah penelitian tentang karakter warrior dalam MMORPG, yang diwakili oleh tiga daerah/zona yaitu: MMORPG dari zona Eropa, zona Asia, serta zona Indonesia. Penelitian ini dilakukan untuk mengetahui kecenderungan zona mana yang menjadi pilihan dari audiens untuk perancangan karakter warrior dalam game online dengan berpedoman pada parameter-paramater yang telah ditentukan yakni: karakteristik wajah, karkateristik badan, pelindung badan (armor), aksesoris (pelengkap), dan senjata. Hasil dari penelitian ini bisa 
dikembangkan lebih lanjut sebagai acuan dalam desain karakter warrior untuk game online, sesuai dengan parameter yang dipilih.

\section{METODE PENELITIAN}

Metode pengumpulan data dilakukan dengan menggunakan metode kuantitatif dengan perangkat utamanya adalah kuisioner VAS (Visual Analog Scale) (Fadinie et al., 2016). Data dari responden yang telah memberikan penilaian terhadap keunggulan dan kelemahan karakter warrior game online yang diasumsikan telah mewakili karakter budaya yang berbeda, selanjutnya akan dianalisis menggunakan metode analisis ANOVA (Analysis of Variance) (Fadinie dkk., 2016). Metode ANOVA yaitu metode analisis data yang menggunakan lebih dari dua sampel percobaan. Berikut adalah tahapan metode ANOVA:

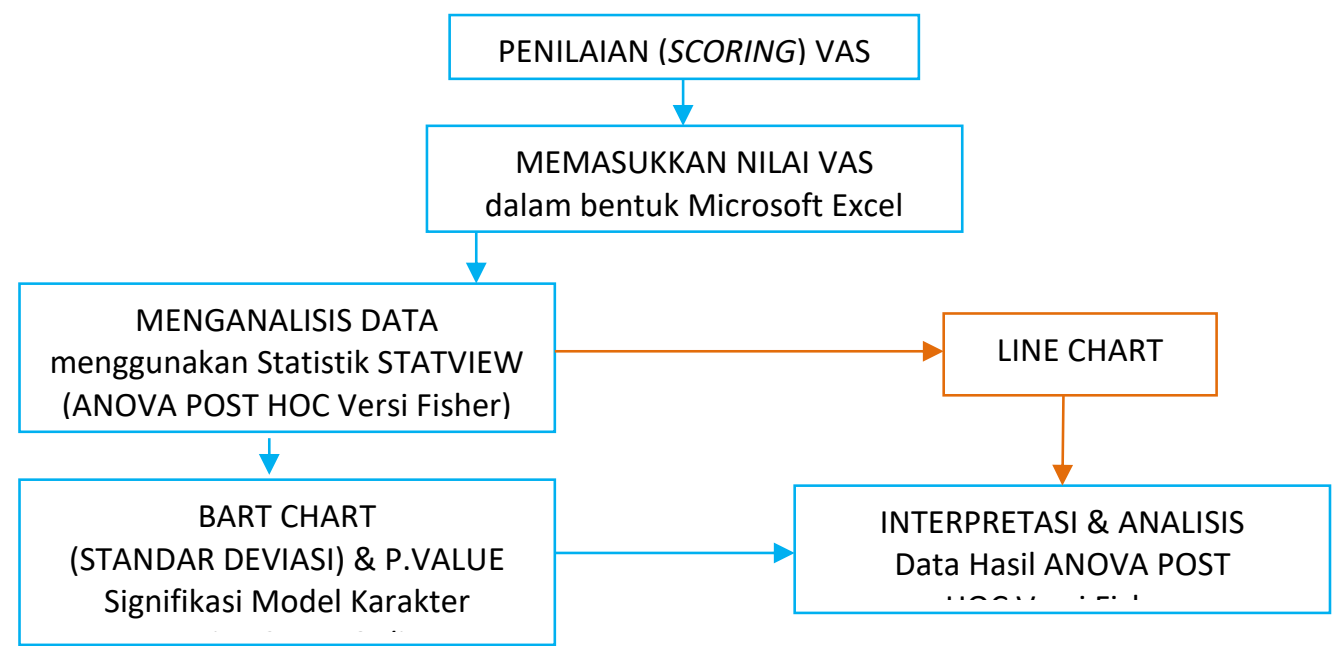

Gambar 1. Tahapan analisis data menggunakan metode ANOVA

Data didapat dari membagikan lembar kuesioner yaitu lembar VAS untuk tiap sampel percobaan yaitu tiap karakter warrior yang berbeda kepada responden kemudian diolah datanya menggunakan Microsoft Excel 2007 dan Statview. Dalam Statview dilakukan analisis ANOVA Post Hoc versi Fisher untuk 
mendapatkan signifikansi data sehingga dapat ditarik suatu kesimpulan dengan perbandingan hasil analisis melalui metode ANOVA tersebut.

\section{HASIL DAN PEMBAHASAN}

\section{Identifikasi Objek Penelitian}

Penelitian ini menganalisis karakter warrior dalam beberapa game online yang dirasa dapat mewakili karakter budaya yang ditampilkan secara visual dalam karakter tersebut. Meliputi penggambaran wajah, badan, pakaian, senjata, dan lain sebagainya. Berikut adalah tiga karakter warrior game online yang dianalisis:

a. Karakter Purist Thunderwrath dalam game online World Of Warcraft, mewakili budaya Eropa.

b. Karakter Wuxia dalam game online Perfect World, mewakili budaya Asia.

c. Karakter Makadga dalam game online Nusantara Online, mewakili budaya Indonesia.

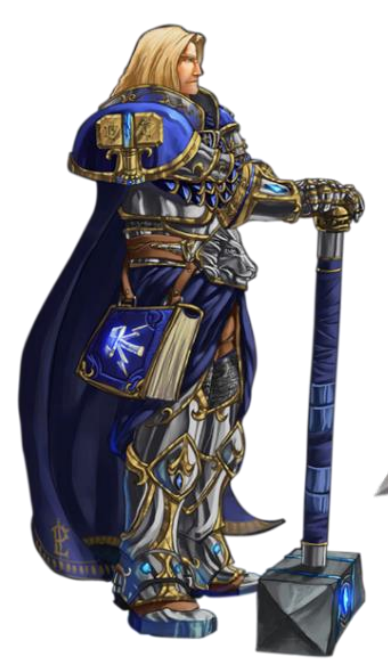

Gambar 2. Karakter 1 Purist Thunderwrath

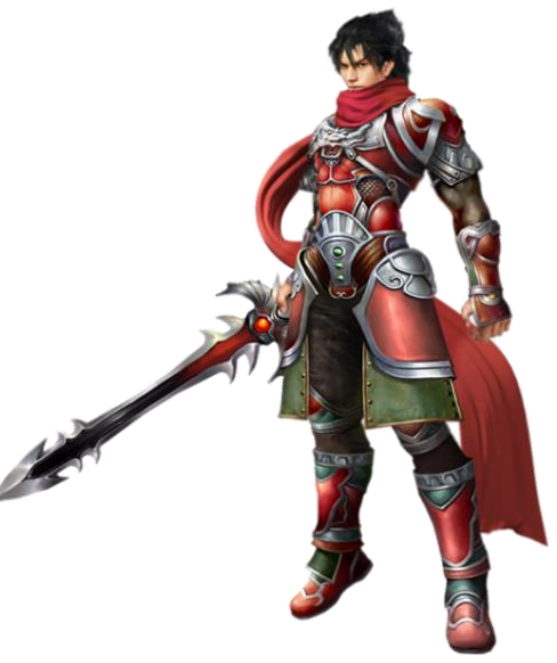

Gambar 3. Karakter 2 Wuxia

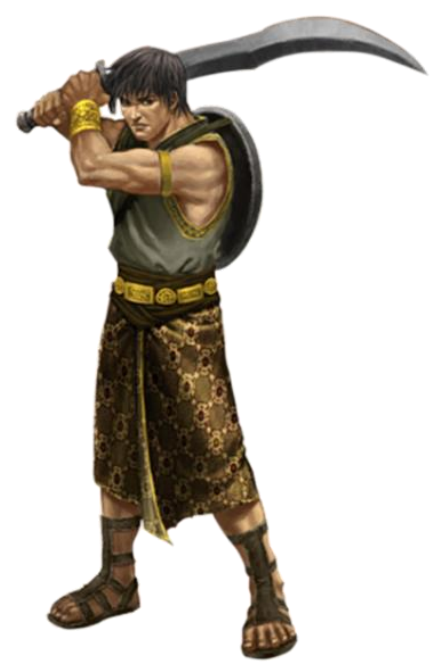

Gambar 4. Karakter 3 Makadga

Ketiga karakter tersebut dipilih karena dianggap telah mewakili tiga corak karakter budaya yang berbeda yaitu karakter Eropa, karakter Asia, dan karakter Indonesia. Dimana karakter Eropa dan Asia telah dikenal lama, sedang karakter 
Indonesia baru-baru ini menampakkan dirinya untuk bersaing dengan kedua karakter lainnya tersebut. Penelitian ini dapat menjadi tolak ukur keunggulan dan kelemahan masing-masing karakter secara visual serta juga untuk menilai seberapa besar minat masyarakat terhadap karakter Indonesia khususnya. Karakter akan dinilai dari beberapa variabel visual yang menjadi tolak ukur keunggulan dan kelemahan karakter, yaitu (1) Tingkat Karakteristik Wajah, (2) Tingkat Karakteristik Badan, (3) Pelindung Badan (Armor), (4) Aksesoris (Pelengkap), dan (5) Senjata.

\section{Analisis Data VAS dengan Metode ANOVA}

Data didapat dari beberapa responden yaitu mahasiswa desain komunikasi visual dan pemain game MMORPG di wilayah kota Bandung yang secara tidak langsung memiliki wawasan visual yang cukup untuk memberikan penilaian yang kompeten terhadap permasalahan penelitian. Responden berjumlah 66 orang dengan 16 responden laki-laki dan 50 responden perempuan. Dalam lembar kuesioner mereka memberikan penilaian terhadap tingkat karakteristik wajah, badan, pelindung badan, aksesoris, dan senjata karakter warrior game online yang ideal bagi mereka. Kemudian data dimasukkan kedalam Microsoft excel 2007 dan dianalisis sebagai berikut:

\section{Karakteristik Wajah}

a. Sebaran Data Mentah $(n=66)$

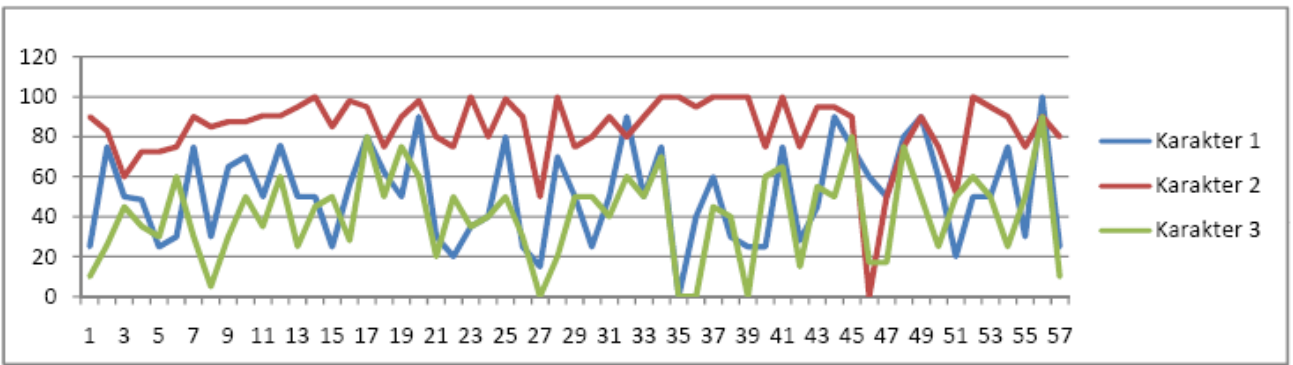

Grafik 1. Hasil analisis data tingkat karakteristik wajah dalam Microsoft excel 


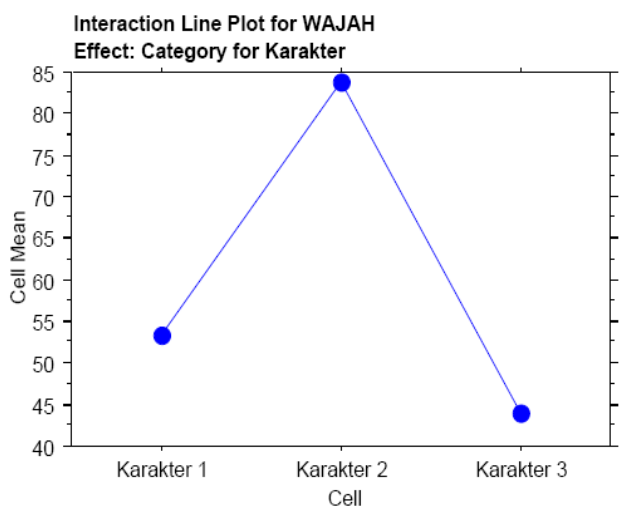

Grafik 2. Data Mean analisis ANOVA pada tingkat karakteristik wajah

Dari dua grafik di atas didapatkan penilaian data dari responden mengenai karakteristik wajah karakter, dimana rataan nilai menunjukkan angka yang signifikan dari tiap karakternya. Sehingga dapat ditarik beberapa analisis, yaitu:

- Karakter 1 dan 2 memiliki kecenderungan nilai di atas rata-rata (>50)

- Karakter 3 memiliki kecenderungan nilai di bawah rata-rata $(<50)$

- Karakter 1 dinilai memiliki wajah yang cukup ideal

- Karakter 2 dinilai memiliki wajah yang paling ideal

- Karakter 3 dinilai memiliki wajah yang kurang ideal.

b. Analisis Gender ( $n=66)$

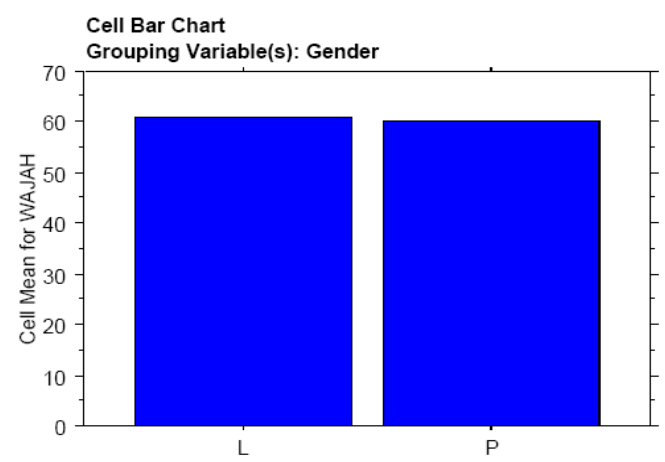

Fisher's PLSD for WAJAH

Effect: Gender

Significance Level: $5 \%$

\begin{tabular}{rr|r|r|}
\multicolumn{1}{c}{ Mean Diff. } & \multicolumn{1}{c}{ Crit. Diff } & \multicolumn{1}{c}{ P-Value } \\
\cline { 2 - 4 } L, P & .527 & 9.090 & .9090 \\
\cline { 2 - 3 }
\end{tabular}

Pada analisis gender tidak terdapat signifikansi data. Kedua rataan nilai dari laki-laki dan perempuan hampir sama, dengan P.Value $=0.9090$. 
Sehingga dapat dianalisis, keduanya memiliki kecenderungan yang sama dalam melihat karakteristik wajah yang ideal pada karakter warrior.

c. Uji ANOVA Post Hoc $(n=66)$

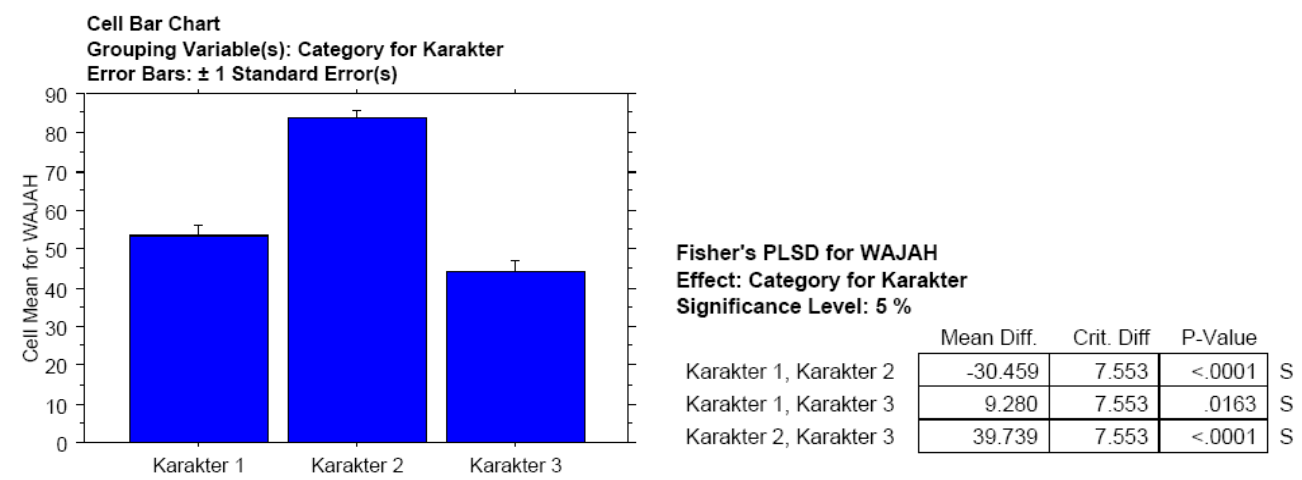

Analisis Signifikansi Tingkat Karakteristik Wajah:

Karakter 1 - Karakter $2=<0.0001$ (Sangat Signifikan)

Karakter 1 - Karakter $3=0.0163$ (Signifikan)

Karakter 2 - Karakter $3=<0.0001$ (Sangat Signifikan)
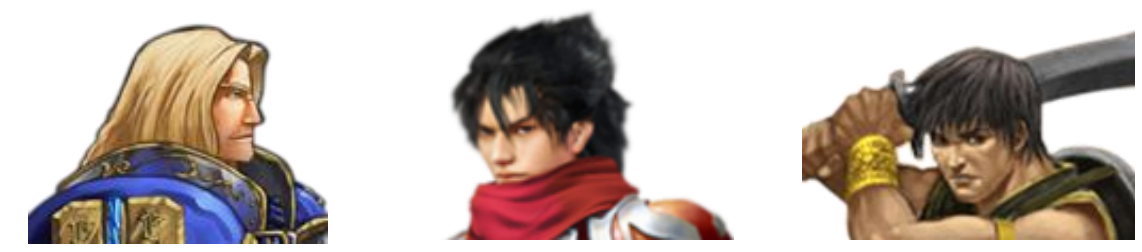

Gambar 5. Perbandingan wajah karakter 1, 2, dan 3

Dari data di atas terlihat perbandingan nilai yang signifikan pada tiap karakternya, sehingga dapat ditarik kesimpulan bahwa secara visual karakter 2 memiliki wajah yang dinilai paling ideal dan karakter 3 memiliki wajah yang dinilai tidak ideal sebagai karakter warrior. Karakter 1 memiliki wajah yang dinilai cukup ideal. Dari kesimpulan data yang diperoleh dapat diasumsikan bahwa kecenderungan responden memilih karakter 2, karakter WUXIA 
sebagai karakter warrior yang memiliki wajah yang paling ideal disebabkan oleh beberapa faktor, yaitu:

1) Paras rupawan, kesan pahlawan, prajurit karena sebagian besar responden adalah perempuan.

2) Representasi muda, enerjik. Ekspresi wajah kharismatik.

3) Game MMORPG yang kebanyakan beredar dan dikenal adalah game dari Asia, sehingga karakter wajah sering dijumpai oleh responden.

\section{Karakteristik Badan}

a. Sebaran Data Mentah ( $n=66)$

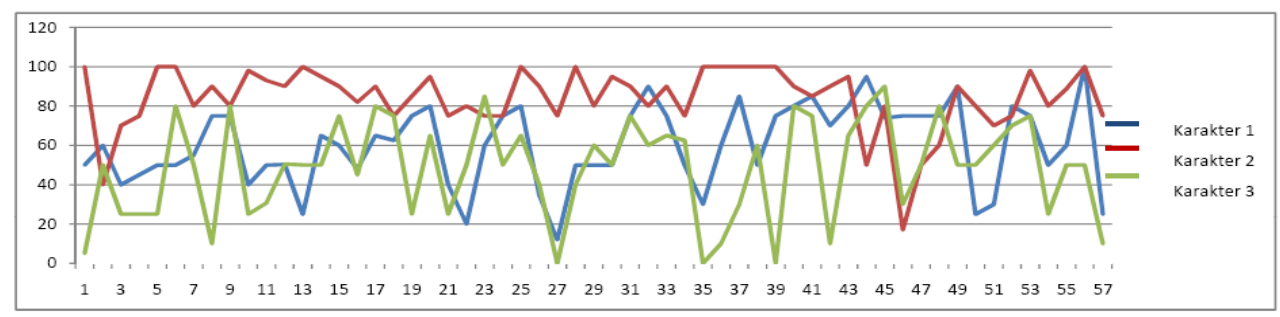

Grafik 3. Hasil analisis data tingkat karakteristik badan dalam Microsoft excel 2007

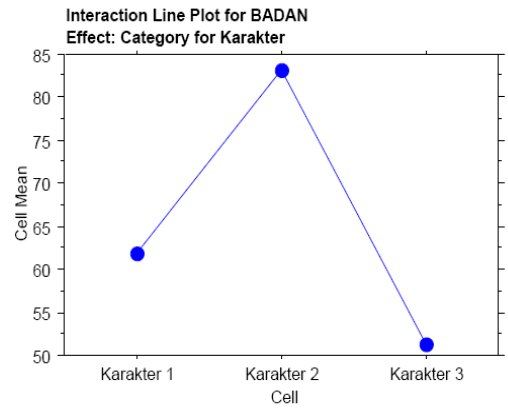

Grafik 4. Data Mean analisis ANOVA pada tingkat karakteristik badan

Dari dua grafik di atas didapatkan penilaian data dari responden mengenai karakteristik badan karakter, dimana rataan nilai menunjukkan angka yang signifikan dari tiap karakternya. Sehingga dapat ditarik beberapa analisis, yaitu:

- Karakter 1, 2, dan 3 memiliki kecenderungan nilai di atas rata-rata (>50). 
- Karakter 1 dinilai memiliki badan yang cukup ideal.

- Karakter 2 dinilai memiliki badan yang paling ideal.

- Karakter 3 dinilai memiliki badan yang kurang ideal.

b. Analisis Gender ( $n=66)$

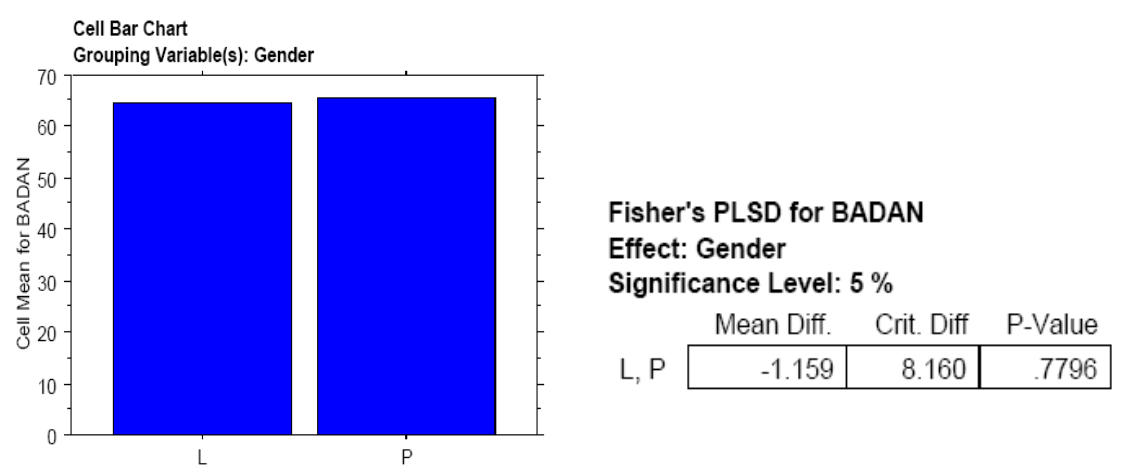

Pada analisis gender tidak terdapat signifikansi data. Kedua rataan nilai dari laki-laki dan perempuan hampir sama, dengan P.Value $=0.7796$. Sehingga dapat dianalisis, keduanya memiliki kecenderungan yang sama dalam melihat karakteristik badan yang ideal pada karakter warrior.

c. Uji ANOVA Post Hoc

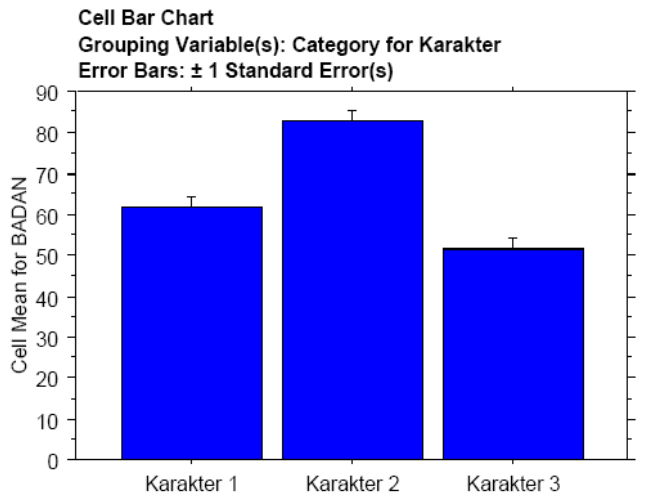

Fisher's PLSD for BADAN

Effect: Category for Karakter

Significance Level: $5 \%$

Karakter 1, Karakter 2

Karakter 1, Karakter 3

Karakter 2, Karakter 3

\begin{tabular}{|r|r|r|r|} 
Mean Diff. & \multicolumn{1}{c}{ Crit. Diff } & \multicolumn{2}{c}{ P-Value } \\
\hline-21.288 & 7.270 & $<.0001$ & $\mathrm{~S}$ \\
\hline 10.502 & 7.270 & .0049 & $\mathrm{~S}$ \\
\hline 31.789 & 7.270 & $<.0001$ & $\mathrm{~S}$
\end{tabular}

Analisis Signifikansi Tingkat Karakteristik Badan:

Karakter 1 - Karakter $2=<0.0001$ (Sangat Signifikan)

Karakter 1 - Karakter $3=0.0049$ (Signifikan)

Karakter 2 - Karakter $3=<0.0001$ (Sangat Signifikan) 
Dari data di atas terlihat perbandingan nilai yang signifikan pada tiap karakternya, sehingga dapat ditarik kesimpulan bahwa secara visual karakter 2 memiliki badan yang dinilai paling ideal dan karakter 3 memiliki badan yang dinilai tidak ideal sebagai karakter warrior. Karakter 1 memiliki badan yang dinilai cukup ideal. Dari kesimpulan data diperoleh dapat diasumsikan bahwa kecenderungan responden memilih karakter 2, karakter WUXIA sebagai karakter warrior yang memiliki badan yang paling ideal disebabkan oleh beberapa faktor, yaitu:

1) Badan karakter yang proporsional (mesomorf), sangat sesuai sebagai sosok petarung (warrior).

2) Representasi gesit, gerakan lincah.

\section{Pelindung Badan (Armor)}

a. Sebaran Data Mentah ( $\mathrm{n}=66)$

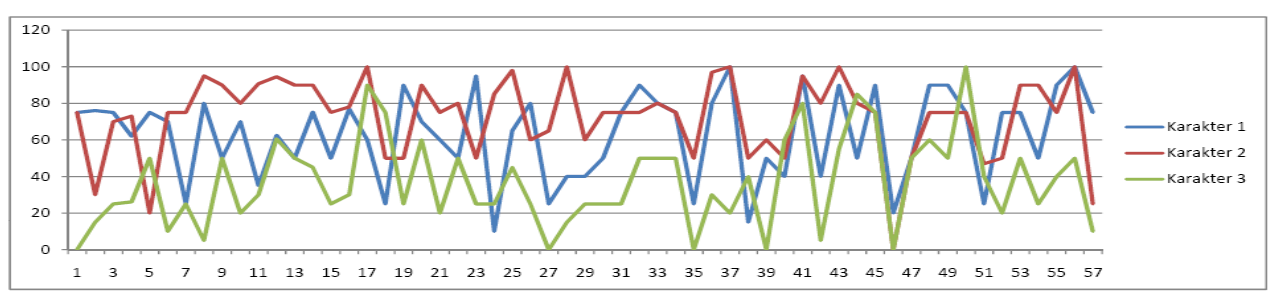

Grafik 5. Hasil analisis data tingkat pelindung badan dalam Microsoft excel 2007

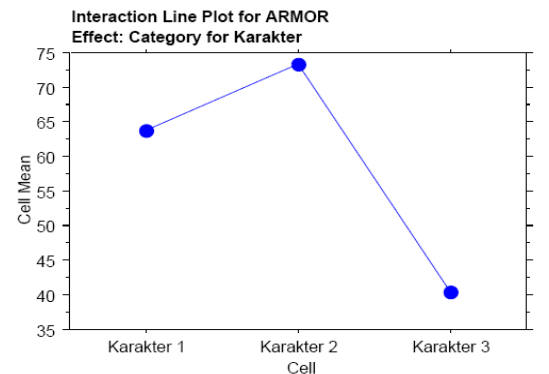

Grafik 6. Data Mean analisis ANOVA pada tingkat armor (pelindung badan)

Berdasarkan dua grafik di atas didapatkan penilaian data dari responden mengenai pelindung badan yang dipakai karakter, dimana rataan 
nilai menunjukkan angka yang cukup signifikan dari tiap karakternya. Sehingga dapat ditarik beberapa analisis, yaitu:

- Karakter 1 dan 2 memiliki kecenderungan nilai di atas rata-rata (>50).

- Karakter 3 memiliki kecenderungan nilai di bawah rata-rata $(<50)$.

- Karakter 1 dinilai memiliki pelindung badan yang cukup baik.

- Karakter 2 dinilai memiliki pelindung badan yang paling baik.

- Karakter 3 dinilai memiliki pelindung badan yang kurang baik.

b. Analisis Gender ( $n=66)$

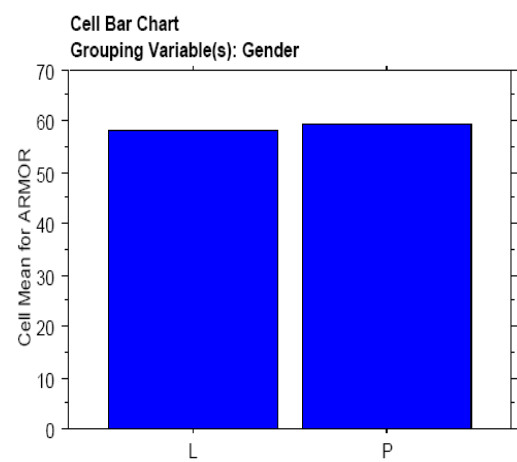

Fisher's PLSD for ARMOR

Effect: Gender

Significance Level: $5 \%$

\begin{tabular}{rr|r|r|}
\multicolumn{1}{c}{ Mean Diff. } & \multicolumn{1}{c}{ Crit. Diff } & \multicolumn{1}{r}{ P-Value } \\
\cline { 2 - 4 }$L, P$ & -1.137 & 8.880 & .8010 \\
\hline
\end{tabular}

Pada analisis gender tidak terdapat signifikansi data. Kedua rataan nilai dari laki-laki dan perempuan hampir sama, dengan P.Value $=0.8010$. Sehingga dapat dianalisis, keduanya memiliki kecenderungan yang sama dalam melihat pelindung badan yang baik/sesuai pada karakter warrior.

c. Uji ANOVA Post Hoc
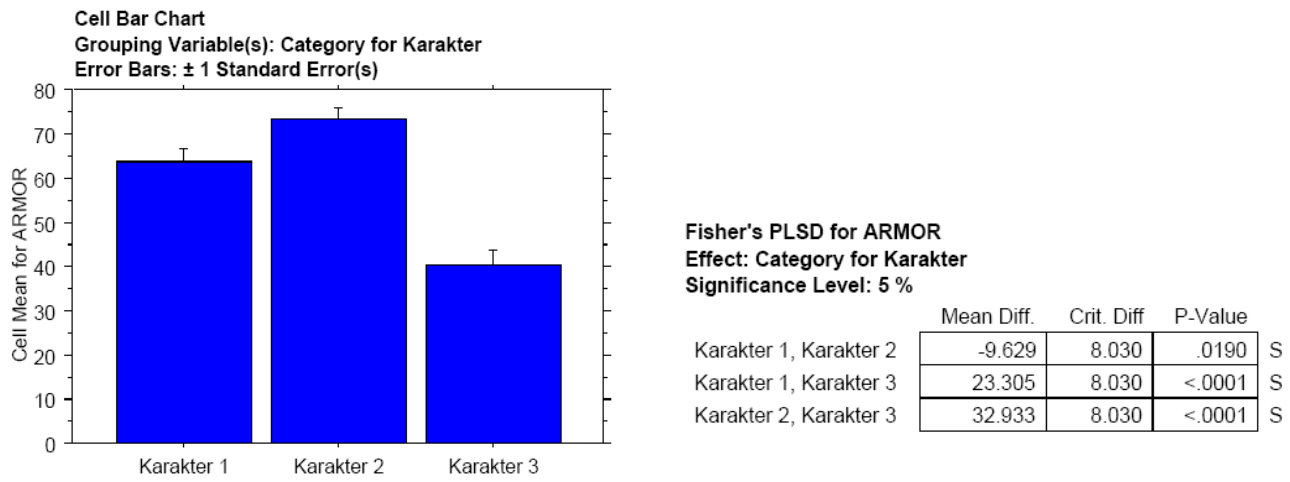

\begin{tabular}{|r|r|r|}
\multicolumn{1}{r|}{ Mean Diff. } & \multicolumn{1}{c}{ Crit. Diff } & \multicolumn{1}{c}{ P-Value } \\
\hline-9.629 & 8.030 & .0190 \\
$\mathrm{~S}$ & $\mathrm{~S}$ \\
\hline 23.305 & 8.030 & $<.0001$ \\
$\mathrm{~S}$ \\
\hline 32.933 & 8.030 & $<.0001$ \\
$\mathrm{~S}$
\end{tabular}


Analisis Signifikansi Tingkat Armor:

Karakter 1 - Karakter $2=0.0190$ (Signifikan)

Karakter 1 - Karakter $3=<0.0001$ (Sangat Signifikan)

Karakter 2 - Karakter $3=<0.0001$ (Sangat Signifikan)

Dari data di atas terlihat perbandingan nilai yang signifikan pada tiap karakternya, sehingga dapat ditarik kesimpulan bahwa secara visual karakter 2 memiliki pelindung badan yang dinilai paling baik dan karakter 3 memiliki pelindung badan yang dinilai tidak baik sebagai karakter warrior. Karakter 1 memiliki pelindung badan yang dinilai cukup baik. Dari kesimpulan data diperoleh dapat diasumsikan bahwa kecenderungan responden memilih karakter 2, karakter WUXIA sebagai karakter yang memiliki pelindung badan yang paling baik disebabkan oleh beberapa faktor, yaitu:

1) Kenyamanan dan fungsi perlindungan yang optimal. Gerak tubuh bebas

2) Desain stylish representasi kewibawaan, kepribadian, kehormatan.

3) Fungsi armor sebagai defense karakter dalam game.

4) Warna armor, merah menunjukkan semangat, kekuatan.

\section{Aksesoris (Pelengkap)}

a. Sebaran Data Mentah $(n=66)$

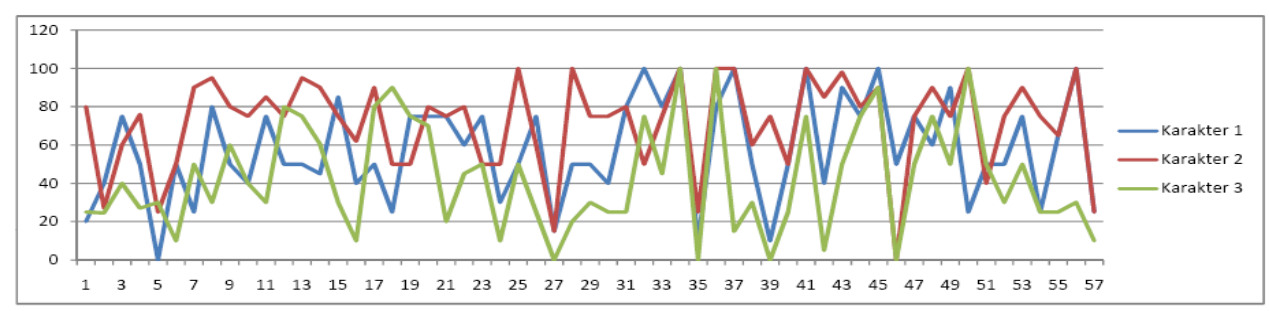

Grafik 7. Hasil analisis data tingkat aksesoris dalam Microsoft excel 2007 


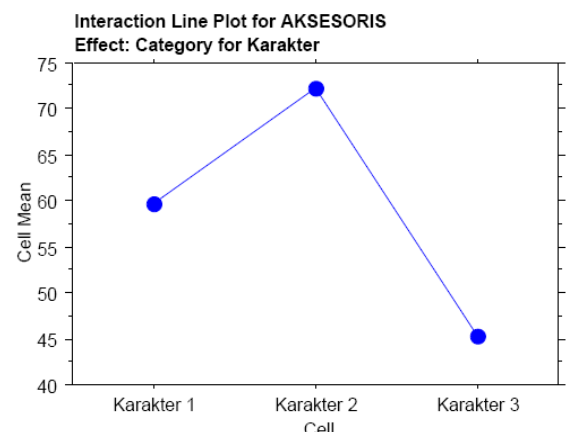

Grafik 8. Data Mean analisis ANOVA pada tingkat aksesoris (pelengkap)

Berdasarkan dua grafik di atas didapatkan penilaian data dari responden mengenai aksesoris yang dipakai karakter, dimana rataan nilai menunjukkan angka yang signifikan dari tiap karakternya. Sehingga dapat ditarik beberapa analisis, yaitu:

- Karakter 1 dan 2 memiliki kecenderungan nilai di atas rata-rata (>50)

- Karakter 3 memiliki kecenderungan nilai di bawah rata-rata $(<50)$

- Karakter 1 dinilai memiliki aksesoris yang cukup sesuai.

- Karakter 2 dinilai memiliki aksesoris yang paling sesuai.

- Karakter 3 dinilai memiliki aksesoris yang kurang sesuai.

b. Analisis Gender ( $n=66)$

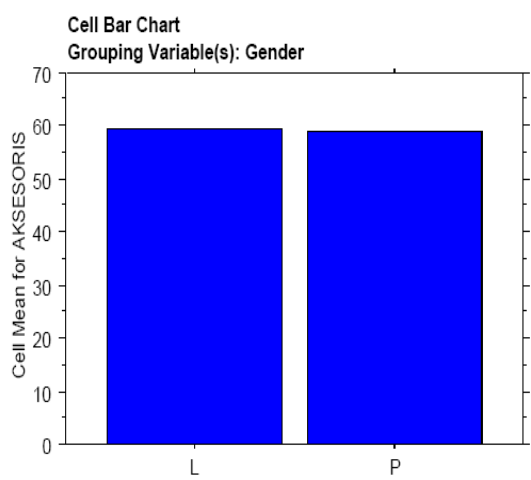

Fisher's PLSD for AKSESORIS

Effect: Gender

Significance Level: $5 \%$

\begin{tabular}{rr|r|r|}
\multicolumn{1}{c}{} & \multicolumn{1}{c}{ Mean Diff. } & \multicolumn{1}{c}{ Crit. Diff } & \multicolumn{1}{c}{ P-Value } \\
\cline { 2 - 4 } L, P & .683 & 9.084 & .8822 \\
\hline
\end{tabular}

Pada analisis gender tidak terdapat signifikansi data. Kedua rataan nilai dari laki-laki dan perempuan hampir sama, dengan P.Value $=0.8822$. Sehingga dapat dianalisis, keduanya memiliki kecenderungan yang sama dalam melihat aksesoris yang sesuai pada karakter warrior. 
c. Uji ANOVA Post Hoc

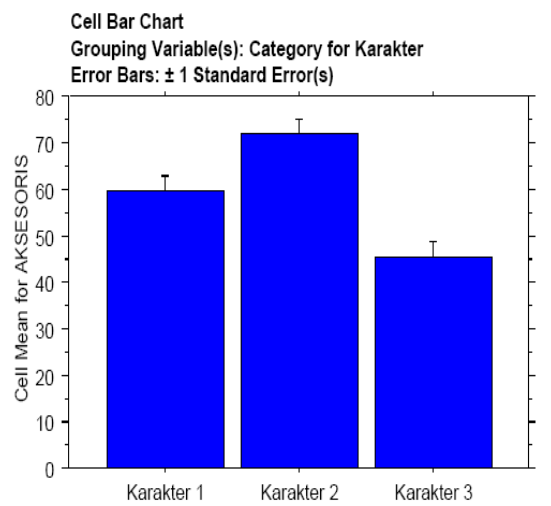

\begin{tabular}{|c|c|c|c|}
\hline \multicolumn{4}{|c|}{$\begin{array}{l}\text { Fisher's PLSD for AKSESORIS } \\
\text { Effect: Category for Karakter } \\
\text { Significance Level: } 5 \%\end{array}$} \\
\hline & Mean Diff. & Crit. Diff & P-Value \\
\hline Karakter 1, Karakter 2 & -12.621 & 8.772 & .0050 \\
\hline Karakter 1, Karakter 3 & 14.288 & 8.772 & .0015 \\
\hline Karakter 2, Karakter 3 & 26.909 & 8.772 & $<.0001$ \\
\hline
\end{tabular}

Analisis Signifikansi Tingkat Aksesoris:

Karakter $1-$ Karakter $2=0.0050$ (Signifikan)

Karakter 1 - Karakter $3=0.0015$ (Signifikan)

Karakter 2 - Karakter $3=<0.0001$ (Sangat Signifikan)

Dari data di atas terlihat perbandingan nilai yang signifikan pada tiap karakternya, sehingga dapat ditarik kesimpulan bahwa secara visual karakter 2 memiliki aksesoris yang dinilai paling sesuai dan karakter 3 memiliki aksesoris yang dinilai tidak. Karakter 1 memiliki aksesoris yang dinilai cukup sesuai. Dari kesimpulan data diperoleh bahwa kecenderungan responden memilih karakter 2, karakter WUXIA sebagai karakter warrior yang memiliki aksesoris yang paling sesuai disebabkan oleh beberapa faktor, yaitu:

1) Kesesuaian dengan pelindung badan (armor).

2) Fungsi aksesoris untuk meningkatkan status karakter dalam game.

\section{Senjata}

a. Sebaran Data Mentah ( $n=66)$

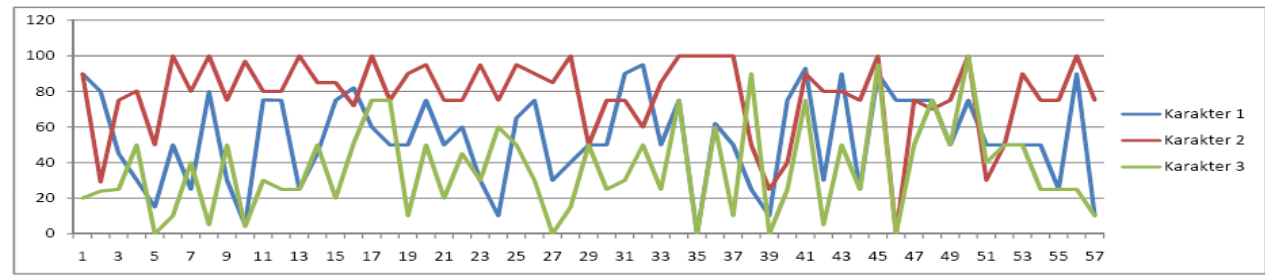

Grafik 9. Hasil analisis data tingkat senjata dalam Microsoft excel 2007 


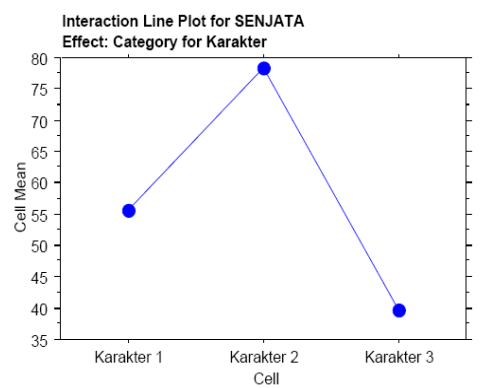

Grafik 10. Data Mean analisis ANOVA pada tingkat senjata yang dipakai

Dari dua grafik di atas didapatkan penilaian data dari responden mengenai senjata yang dipakai karakter, dimana rataan nilai menunjukkan angka yang signifikan dari tiap karakternya. Sehingga dapat ditarik beberapa analisis, yaitu:

- Karakter 1 dan 2 memiliki kecenderungan nilai di atas rata-rata (>50)

- Karakter 3 memiliki kecenderungan nilai di bawah rata-rata $(<50)$

- Karakter 1 dinilai memiliki senjata yang cukup sesuai

- Karakter 2 dinilai memiliki senjata yang paling sesuai

- Karakter 3 dinilai memiliki senjata yang kurang sesuai

b. Analisis Gender ( $n=66)$

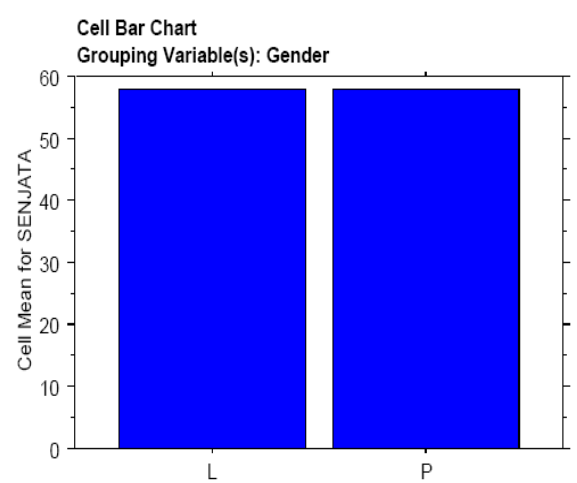

Fisher's PLSD for SENJATA

Effect: Gender

Significance Level: $5 \%$

\begin{tabular}{rr|r|r|}
\multicolumn{1}{c}{ Mean Diff. } & \multicolumn{1}{c}{ Crit. Diff } & \multicolumn{1}{c}{ P-Value } \\
\cline { 2 - 4 } L, P & -.114 & 9.504 & .9812 \\
\hline
\end{tabular}

Pada analisis gender tidak terdapat signifikansi data. Kedua rataan nilai dari laki-laki dan perempuan hampir sama, dengan P.Value $=0.9812$. Sehingga dapat dianalisis, keduanya memiliki kecenderungan yang sama dalam melihat senjata yang sesuai pada karakter warrior. 
c. Uji ANOVA Post Hoc

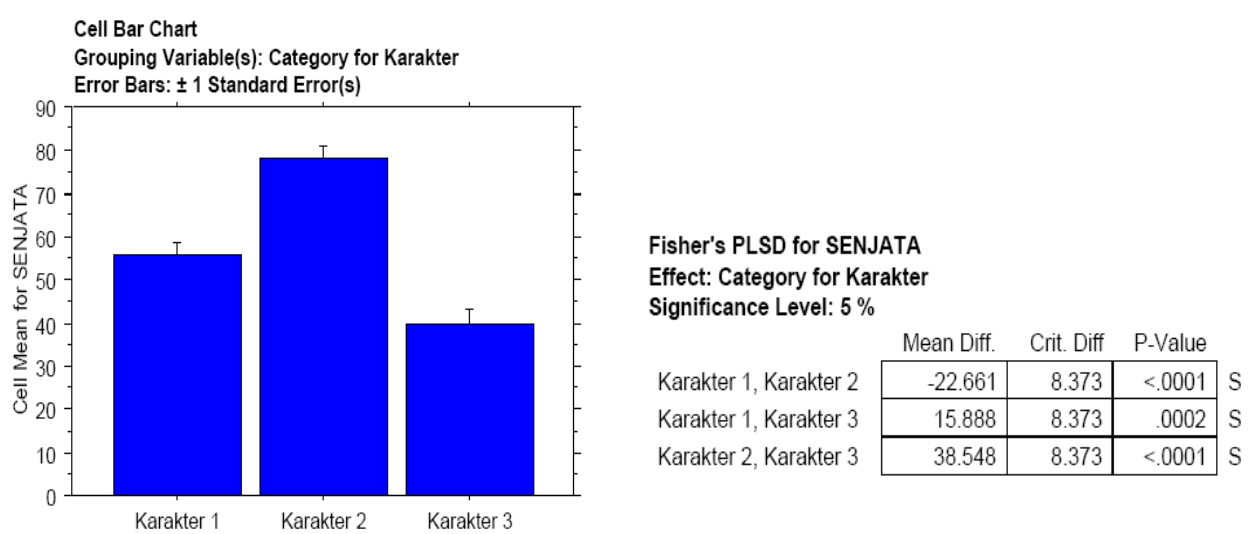

Analisis Signifikansi Tingkat Senjata:

Karakter 1 - Karakter $2=<0.0001$ (Sangat Signifikan)

Karakter 1 - Karakter $3=0.0002$ (Signifikan)

Karakter 2 - Karakter $3=<0.0001$ (Sangat Signifikan)

Dari data di atas terlihat perbandingan nilai yang sangat signifikan pada tiap karakternya, sehingga dapat ditarik kesimpulan bahwa secara visual karakter 2 memiliki senjata yang dinilai paling sesuai dan karakter 3 memiliki senjata yang dinilai tidak sesuai sebagai karakter warrior. Karakter 1 memiliki senjata yang dinilai cukup sesuai. Dari kesimpulan data diperoleh dapat diasumsikan bahwa kecenderungan responden memilih karakter 2 sebagai karakter warrior dalam game online yang memiliki senjata yang paling sesuai disebabkan oleh beberapa faktor, yaitu:

1) Kemampuan senjata sebagai senjata pembunuh paling efektif.

2) Persepsi responden bahwa pedang adalah senjata para warrior.

3) Ergonomis senjata yang mudah dibawa dan dipegang. 


\section{KESIMPULAN}

Setelah data dari responden dianalisis melalui metode ANOVA Post Hoc Versi Fisher didapatkan beberapa perbandingan nilai dan kesimpulan mengenai tipe karakter warrior game online yang ideal bagi responden. Berikut adalah beberapa kesimpulan dari analisis data tersebut:

a. Pada analisis gender tidak terdapat signifikansi data. Hal ini menunjukkan bahwa penilaian dari responden laki-laki dan perempuan hampir sama tentang karakter warrior game online yang ideal pada tingkat karakteristik wajah, karakteristik badan, pelindung badan, aksesoris (pelengkap), dan senjata.

b. Keseluruhan data pada tingkat karakteristik wajah, karakteristik badan, pelindung badan, aksesoris, dan senjata menunjukkan superioritas karakter 2 , karakter Wuxia sebagai karakter warrior game online yang paling ideal.

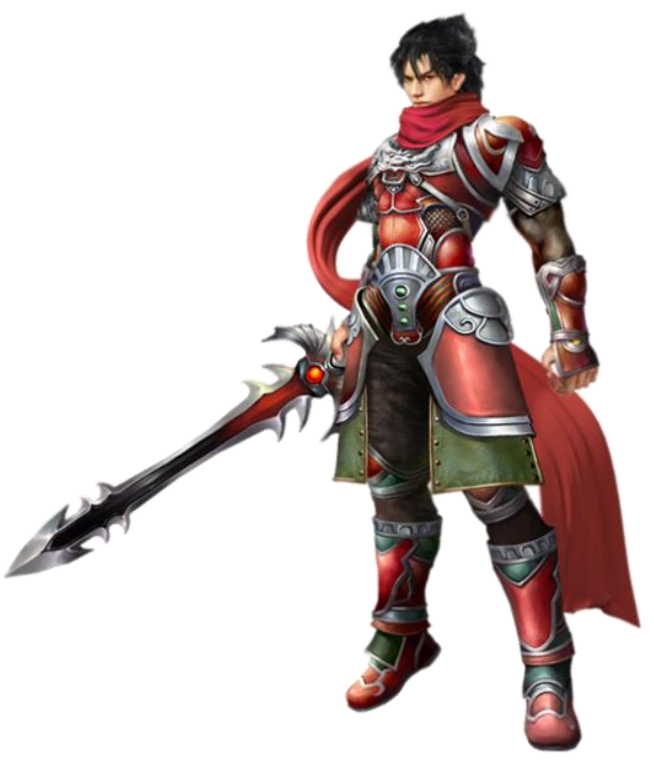

Gambar 6. Karakter 2 Wuxia menjadi karakter paling ideal pilihan responden dari keseluruhan karakteristik visual vang diberikan

c. Tipe karakter dengan paras rupawan dan tubuh proporsional dianggap sebagai perwujudan sosok petarung (warrior) yang ideal dan disukai oleh responden. 
d. Kecenderungan responden melihat karakter warrior memiliki pelindung tubuh (armor) yang menutupi seluruh tubuh karena fungsinya sebagai pertahanan dalam pertarungan, dan secara visual terlihat nyaman untuk dikenakan.

e. Aksesoris dinilai penting untuk meningkatkan status karakter.

f. Senjata yang paling efektif untuk membunuh musuh merupakan tipe senjata pedang. Disamping nilai ergonomisnya, secara visual tidak terlihat berat, mudah diayunkan.

Penelitian ini bisa dikembangkan lebih jauh tidak hanya menganalisis karakter berdasarkan latar belakang budayanya, tetapi juga bisa menjadi acuan dalam desain karakter tipe warrior game online sesuai dengan konsep dan tema yang diusung atau berdasarkan latar belakang cerita game yang akan dikembangkan. Agar penelitian selanjutnya dengan data yang lebih akurat dan hasil analisisnya dapat digunakan sebagai acuan bagi pengembangan model karakter warrior yang ideal, maka penelitian ini memerlukan beberapa perbaikan,yaitu:

a. Perbandingan jumlah responden laki-laki dan perempuan yang berimbang agar pada analisis gender menunjukkan signifikansi yang lebih akurat.

b. Data responden dilengkapi dengan latar belakang pengalamannya memainkan game online sehingga responden mengenal baik masalah penelitian yaitu menentukan karakter warrior yang ideal dalam game online.

c. Stimuli visual berupa karakter yang dikomparasikan, setidaknya memiliki ciriciri yang hampir sama. Terutama mengenai parameter senjata. Senjata yang dibandingkan masih dalam satu tipe, yang dilihat dari segi fungsi, segi kamampuan senjata dalam membunuh lawan, serta segi bentuk fisik dari senjata itu sendiri. Hal ini akan lebih memudahkan responden dalam memberikan penilaian yang lebih objektif. 


\section{DAFTAR PUSTAKA}

Bastian, H. dan Khamadi, K., 2016. Dampak Digital Game Terhadap Perkembangan Sosial Budaya Masyarakat. Jurnal Andharupa Vol 2, No 1, 33-44.

Estidianti, B.R., Lakoro, R., 2014. Perancangan Karakter Game Visual Novel "Tikta Kavya" Dengan Konsep Visual Bishonen. Jurnal Sains Dan Seni ITS, Vol.3, No.2, 49-54.

Fadinie, W., Arifin, H., Wijaya, D.W., 2016. Perbandingan Penilaian Visual Analog Scale dari Injeksi Subkutan Morfin $10 \mathrm{mg}$ dan Bupivakain 0,5\% pada Pasien Pascabedah Sesar dengan Anestesi Spinal. Jurnal Anestesi Perioper, Vol. 4, No. 2, 117-123.

Fajrin, J., Pathurahman, P., Pratama, L.G., 2016. Aplikasi Metode Analysis Of Variance (Anova) untuk Mengkaji Pengaruh Penambahan Silica Fume Terhadap Sifat Fisik dan Mekanik Mortar. Jurnal Rekayasa Sipil JRSUnand, Vol. 12, No.1.

Khamadi, K., 2015. Analisis Tampilan Visual Game Super Mario Bros Dalam Kajian Persepsi Visual Sebagai Dasar Pengembangan Konsep Visual Game. Jurnal Andharupa, Vol.1, No.2, 98-109.

Khamadi, K., Senoprabowo, A., 2016. Model Adaptasi Permainan Papan Tradisional Macanan ke Dalam Perancangan Permainan Digital. Jurnal Andharupa, Vol.2, No. 2, 167-180.

Pattiasina, D.L., 2014. Kajian Estetika dan Realisme Sosialis Tiga Patung Monumen (Patung Selamat Datang, Pembebasan Irian Barat dan Dirgantara) Era Soekarno di Jakarta. Jurnal IImiah Widya, Vol. 2, No. 1, 53-61.

Pusposari, A.B., Lakoro, R., 2017. Perancangan Karakter Game RPG Berdirinya Kerajaan Singosari untuk Aplikasi Permainan dengan Gaya Visual Chibi. Jurnal Sains Dan Seni ITS, Vol. 5, No.2, 127-132.

Salma, I.R., 2012. Kajian Estetika Desain Batik Khas Mojokerto "Surya Citra Majapahit." Jurnal Ornamen, Vol. 9, No. 2, 123-136.

Senoprabowo, A., 2015. Analisis Gameplay Game Genre Virtual Pet. Jurnal Andharupa, Vol. 1, No. 1, 33-44. 